\title{
SeKolah Alam BengaWan Solo \\ Dengan Pendekatan Ekologi Arsitektur Di KABUPATEN KLATEN
}

\author{
Hikmatyar Abdul Aziz, Bambang Triratma, Amin Sumadyo \\ Program Studi Arsitektur \\ Fakultas Teknik \\ Universitas Sebelas Maret Surakarta \\ Email : hikmatyarabdulaziz@gmail.com
}

\begin{abstract}
Design of the School of Natural Bengawan Solo in Klaten motivated by formal school education as children when space is in fact still can not be said to ideal for education and develop interest in the child's talents. Education became a fundamental necessity for everyone today. This then raises the idea to present alternative educational space able to accommodate the needs of children to learn, play, and explore. Empowering communities to be able to optimize the potential to become one of the important objects in presenting educational space. Bengawan Solo river and wood craft into the potential of rural communities Gondangsari, Juwiring, Klaten. Potentials possessed villagers Gondangsari not managed properly due to lack of containers in order to accommodate and develop this potential. Design issues are: how to design an alternative education space and bring the space community development based on the application of Ecological Architecture into the design of the School of Natural Solo. The method used is a method of architectural design that blends the essence of Ecological Architecture according to Heinz Frick and Kenneth Yeang in accordance with the design of the School of Natural Solo. Then blend the essence of Ecological Architecture into the design strategies in the design essence a result of interaction of school, nature, and potential kawaasan. The result is a draft design of an educational facility such as classrooms, laboratories of nature, community development space, exhibition space and its supporting buildings which also functions as a precedent alternative education for the visitors.
\end{abstract}

Keywords: Schools, Natural, Bengawan Solo, Architecture Ecology.

\section{PENDAHULUAN}

Sekolah menjadi kebutuhan mendasar bagi semua orang, apalagi di zaman yang semakin mengedepankan pendidikan sebagai salah satu tolok ukur dan penilaian. Sekolah dianggap sebagai rumah kedua untuk mendapatkan pendidikan setelah pendidikan didapat melalui keluarga. Istilah sekolah memang sudah tidak asing lagi, bahkan anak usia dini pun sudah mengenal bahwa sekolah itu seperti apa dan sepenting apa. Prakteknya, makna sekolah sebagai ruang edukasi bagi anak saat ini masih belum dapat dikatakan ideal untuk mengembangkan minat dan bakat anak.

Sekolah alam adalah salah satu bentuk pendidikan alternatif yang menggunakan alam sebagai media utama sebagai pembelajaran siswa didiknya. Tidak seperti sekolah biasa yang lebih banyak menggunakan metode belajar mengajar di dalam kelas, para siswa belajar lebih banyak di alam terbuka.
Kelebihan sekolah alam dibandingkan sekolah biasa, sekolah alam membuat anak tidak terpaku hanya pada teori saja. Mereka dapat mengalami langsung pengetahuan yang mereka pelajari di alam. Karena diakui saat ini sekolah-sekolah biasa lebih banyak menggunakan sistem belajar mengajar konvensional dimana guru menerangkan, siswa hanya mendapat pengetahuan dengan mengandalkan buku panduan saja, dan siswa jarang diberikan kesempatan untuk mengalami langsung atau melihat langsung bentuk pengetahuan yang mereka pelajari. Pendekatan yang dilakukan guna membentuk karakter yang kuat pada anak.

Sungai Bengawan Solo merupakan sungai terpanjang di Pulau Jawa yang melalui berbagai macam desa, salah satunya adalah Desa Gondangsari yang terletak di Kabupaten Klaten. Sungai sebagai salah satu elemen geografis suatu daerah memiliki peranan dan pengaruh penting terhadap daerah 
disekitarnya. Suatu keunggulan geografis tersebut dapat dimanfaatkan oleh daerah terkait dalam menyusun perencanaan dan pengembangan daerah untuk skala waktu yang panjang. Hal tersebut juga sudah banyak diterapkan di berbagai tempat bagaimana potensi alam dijadikan sebuah acuan dalam pengembangan kawasan, seperti di Kota Venice, Itali. Sungai Bengawan Solo sampai sekarang menjadi sesuatu yang sangat diperlukan bagi masyarakat dalam mencukupi kebutuhan hidup. Terlihat jelas kawasan tepi Sungai Bengawan Solo sangat subur dan hijau. Selain menjadi pemasok air untuk lahan pertanian, Sungai Bengawan solo juga memiliki potensi yang sangat besar lainnya. Tetapi masyarakat kurang paham akan besarnya manfaat Sungai Bengawan Solo sebagai sebuah potensi alam sehingga potensi tersebut tidak teroptimalkan dengan baik.

Terdapat permasalahan yang sudah menjadi masalah umum dalam masyarakat pada Desa Gondangsari sebagai lokasi obyek rancang bangun, yakni masih kurangnya ruang pemberdayaan masyarakat. Perlu adanya ruang pemberdayaan masyarakat guna meningkatkan kualitas hidup pada daerah tersebut. Di sisi lain terdapat potensi sumber daya manusia yang melimpah pada Desa Gondangsari. Terdapat industri rumahan dan pengrajin kayu yang mendominasi mata pencaharian warga setempat. Disini terdapat sebuah fenomena yang saling bertentangan yakni banyaknya potensi yang dapat digali dan dikembangkan akan tetapi tidak terdapat wadah pembinaan dan pemberdayaan masyarakat. Perlu adanya ruang eksplorasi dan pengembangan bagi mereka memasarkan karya dan produk hasil industri guna meningkatkan perekonomian masyarakat Desa Gondangsari.

Ekologi Arsitektur menurut Frick (1998) merupakan pendekatan yang tepat dengan konsep sekolah alam yang mencoba menghadirkan metoda perancangan yang berbasis pada alam. Karena pembahasan ekologi tidak lepas dari pembahasan ekosistem dengan berbagai komponen penyusunnya dan lingkungan. Ekologi juga berhubungan erat dengan tingkatan-tingkatan organisasi makhluk hidup, yaitu populasi, komunitas, dan ekosistem yang saling memengaruhi dan merupakan suatu sistem yang menunjukkan kesatuan. Kesatuan yang dihadirkan alam menjadi sebuah media pembelajaran yang baik bagi anak untuk berkembang dan memahami lingkungan di sekitarnya. Peserta didik akan belajar bagaimana merawat kesatuan dari ekosistem yang dibentuk alam melalui metode pembelajaran yang dihadirkan oleh sekolah alam.

Jadi secara keseluruhan esensi judul yang dibangun adalah suatu upaya perencanaan dan perancangan sekolah alam yang berlokasi di kawasan tepi Sungai Bengawan Solo yang memiliki beragam potensi alam serta berangkat pula dari kesenjangan dan degradasi yang timbul. Perencanaan dan perancangan sekolah alam ini merupakan bentuk kepedulian terhadap krisis yang terjadi di dunia pendidikan saat ini. Sekolah alam selain menjadi ruang edukasi bagi anak juga menjadi wadah pemberdayaan masyarakat Desa Gondangsari. Ekologi Arsitektur menjadi sebuah metoda pendekatan desain yang digunakan dalam proses perancangan karena korelasi dan relevansinya terhadap esensi yang terbangun dari permasalahan judul yang hadir.

\section{METODE}

A. Membangun Gagasan dari Fenomena

Penentuan gagasan awal yang mendasari alasan melakukan perancangan Sekolah Alam Bengawan Solo berawal dari munculnya fenomena sekolah formal sebagai ruang edukasi anak saat ini kenyataannya masih belum dapat dikatakan ideal untuk menyelenggarakan pendidikan dan mengembangkan minat bakat anak. Pendidikan menjadi kebutuhan mendasar bagi semua orang di zaman sekarang. Hal ini kemudian memunculkan gagasan untuk menghadirkan ruang pendidikan alternatif yang mampu mengakomodir kebutuhan anak guna belajar, bermain, dan bereksplorasi.

Pemberdayaan masyarakat supaya mampu mengoptimalkan potensinya menjadi salah satu obyek penting dalam menghadirkan ruang edukasi. Sungai Bengawan Solo dan kerajinan kayu menjadi potensi masyarakat Desa 
Gondangsari, Juwiring, Klaten. Potensipotensi yang dimiliki masyarakat Desa Gondangsari tidak terkelola dengan baik dikarenakan belum adanya wadah guna mengakomodir dan mengembangkan potensi tersebut.

Oleh karena itu, untuk memberikan fasilitas pendidikan alternatif dan ruang pemberdayaan masyarakat maka dirancang Sekolah Alam Bengawan Solo.

\section{B. Penerapan Strategi Desain}

Ekologi Arsitektur menjadi pendekatan yang sesuai dengan konsep Sekolah Alam mencoba menghadirkan metoda perancangan yang berbasis pada alam. Pembahasan ekologi tidak lepas dari pembahasan ekosistem dengan berbagai komponen penyusunnya. Ekologi juga berhubungan erat dengan tingkatan-tingkatan organisasi makhluk hidup, yaitu populasi, komunitas, dan ekosistem yang saling memengaruhi dan merupakan suatu sistem yang menunjukkan kesatuan. Kesatuan yang dihadirkan alam menjadi sebuah media pembelajaran yang baik bagi anak untuk berkembang dan memahami lingkungan di sekitarnya. Siswa akan belajar bagaimana merawat kesatuan dari ekosistem yang dibentuk alam melalui metode pembelajaran yang dihadirkan oleh sekolah alam.

Prinsip-prinsip Ekologi Arsitektur menurut beberapa ahli pada buku Metode Perancangan Arsitektur Ekologi karya Yuliani (2014) terutama merujuk kepada Heinz Frick dan Kenneth Yeang (lihat Tabel 1 dan 2) yang manifestasi prinsipnya dapat diimplementasikan sebagai metode desain (lihat Gambar 1) Sekolah Alam Bengawan Solo adalah sebagai berikut:

1. Infrastuktur iklim, penggunaan material, tumbuhan, dan air yang responsif terhadap iklim setempat sebagai pengatur iklim.

2. Infrastuktur energi, penggunaan bahan bangunan yang dapat dibudidayakan dan yang menghemat energi.
3. Infrastruktur air, drainase berkelanjutan yaitu dengan sistem konservasi air dan pengelolaan hidrologi.

4. Infrastuktur rekayasa, yaitu jalan, saluran air, utilitas dll. sebagai pendukung sistem berkelanjutan.

5. Infrastuktur manusia, yaitu lingkungan binaan, termasuk pemberdayaan manusia dan sistem sosial ekonomi.

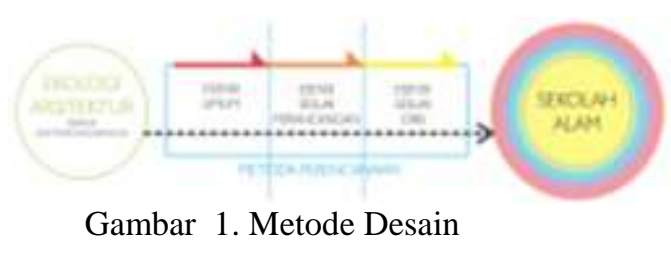

Tabel 1. Esensi Umum

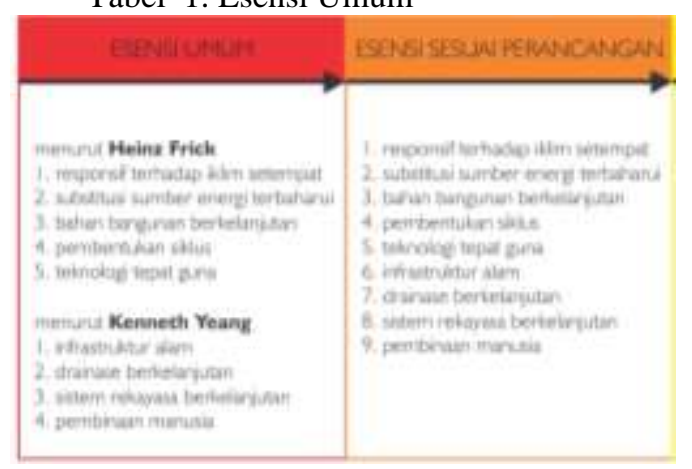

Tabel 2. Esensi Sesuai ORB

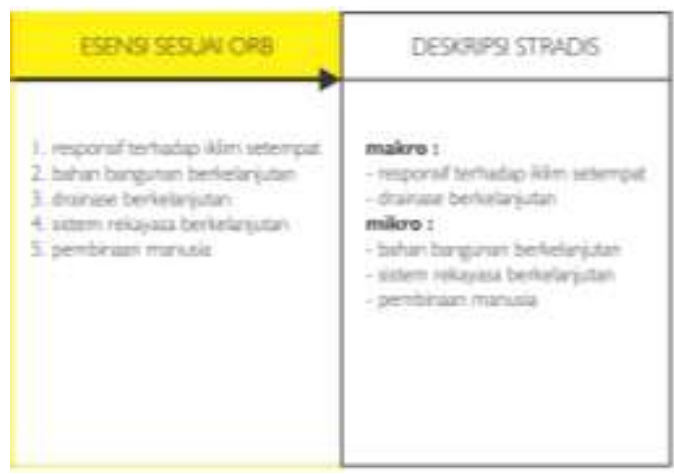

III. ANALISIS

A. Analisis Peruangan

1. Tujuan

Menentukan dan mengelompokkan kebutuhan ruang dalam bangunan

Sekolah Alam Bengawan Solo dengan pendekatan Ekologi Arsitektur di Kabupaten Klaten yang direncanakan.

2. Dasar Pertimbangan
a. Pelaku Kegiatan 
b. Macam Kegiatan

c. Kebutuhan Ruang

3. Proses Analisis

Analisis peruangan menyajikan berbagai macam jenis pelaku, apa saja kegiatan yang dilakukan di dalamnya, serta ruangan-ruangan apa sajakah yang diperlukan di Sekolah Alam Bengawan Solo (lihat Tabel 3).

Tabel 3. Kebutuhan Ruang

\section{B. Analisis Lokasi}

Pemilihan lokasi dilakukan dengan membandingkan tiga lokasi yang dianggap berpotensi lalu menilai kelebihan dan kekurangannya masing-masing (lihat Tabel 4).

1. Tujuan

Memilih lokasi tapak yang strategis, nyaman, dan memiliki banyak potensi yang menunjang proses pembelajaran

\begin{tabular}{|l|l|l|}
\hline $\begin{array}{l}\text { Pelaku } \\
\text { Kegiatan }\end{array}$ & $\begin{array}{l}\text { Macam } \\
\text { Kegiatan }\end{array}$ & $\begin{array}{l}\text { Kebutuhan } \\
\text { Ruang }\end{array}$ \\
\hline $\begin{array}{l}\text { Kepala } \\
\text { Gekolah/ }\end{array}$ & Datang & Gerbang \\
& Memasuki & Entrance \\
& Gedung & \\
& Istirahat \\
(duduk) & Ruang Guru \\
& Pembelajaran & Ruang Kelas \\
& Metabolisme & Kamar mandi \\
& Kerohanian & Mushola \\
& Kesehatan & Medical \\
& Center \\
\hline Siswa & Melihat & Ruang \\
& Informasi & informasi \\
& Pembelajaran & Ruang Kelas \\
& Laboratorium & Laboratorium \\
& Berkumpul, & Alam \\
& duduk & Hall \\
& Makan dan & Perpustakaan \\
& minum & Kantin \\
& Metabolisme & Kamar Mandi \\
& Kerohanian & Mushola \\
& Kesehatan & Medical \\
& Rekreasi/Olah & Center \\
& Raga & Lapangan \\
& Kegiatan & Olah Raga \\
& Multimedia & R. Multimedia \\
& Kegiatan & Student Center \\
& Ekstrakulikuler & \\
\hline
\end{tabular}

\begin{tabular}{|l|l|l|}
\hline $\begin{array}{l}\text { Orang } \\
\text { Tua/Wali } \\
\text { murid }\end{array}$ & $\begin{array}{l}\text { Datang } \\
\text { Berkonsultasi } \\
\text { dengan guru } \\
\text { Mendampingi } \\
\text { Murid } \\
\text { Makan dan } \\
\text { minum } \\
\text { Metabolisme }\end{array}$ & $\begin{array}{l}\text { Gerbang } \\
\text { Ruang Guru } \\
\text { Ruang Kelas } \\
\text { Kantin } \\
\text { Kamar mandi }\end{array}$ \\
\hline $\begin{array}{l}\text { Pengelola } \\
\text { Sekolah }\end{array}$ & $\begin{array}{l}\text { Menyiapkan } \\
\text { operasional } \\
\text { Pelayanan } \\
\text { Operasional } \\
\text { Metabolisme }\end{array}$ & $\begin{array}{l}\text { Ruang } \\
\text { Pengelola } \\
\text { Sekolah } \\
\text { Gudang dan } \\
\text { dapur } \\
\text { Kamar Mandi }\end{array}$ \\
\hline $\begin{array}{l}\text { Tamu/Pe } \\
\text { ngunjung }\end{array}$ & $\begin{array}{l}\text { Mencari } \\
\text { informasi } \\
\text { Istirahat } \\
\text { Makan dan } \\
\text { minum } \\
\text { Metabolisme }\end{array}$ & $\begin{array}{l}\text { Ruang } \\
\text { informasi } \\
\text { Ruang } \\
\text { Tunggu Tamu } \\
\text { Kantin } \\
\text { Kamar mandi }\end{array}$ \\
\hline Satpam & $\begin{array}{l}\text { Menjaga } \\
\text { ketertiban }\end{array}$ & Ruang Satpam \\
\hline
\end{tabular}

pada banungan Sekolah Alam Bengawan Solo dengan pendekatan Ekologi Arsitektur di Kabupaten Klaten yang direncanakan.

2. Dasar Pertimbangan

a. Tapak memiliki luasan yang cukup

b. Lokasi berada di Kabupaten Klaten, Jawa Tengah, Indonesia

c. Luas tapak yang mencukupi untuk kebutuhan besaran ruang yang direncanakan.

d. Memiliki kondisi lingkungan alam sekitar yang menunjang proses pembelajaran.

3. Proses Analisis

Tabel 4. Pemilihan Tapak

\begin{tabular}{|l|l|l|}
\hline No & $\begin{array}{l}\text { Alternatif Lokasi } \\
\text { Tapak }\end{array}$ & Deskripsi \\
\hline 1. & & $\begin{array}{l}\text { Berada di Desa } \\
\text { Serenan } \\
\text { Lokasi mudah } \\
\text { diakses } \\
\text { Berbatasan dengan } \\
\text { Jalan Raya Cuplik } \\
\text { Kontur tanah } \\
\text { cukup } \\
\text { bergelombang } \\
\text { Luasan tapak } \pm \\
8450 \mathrm{~m}^{2}\end{array}$ \\
\hline & 8 \\
\hline
\end{tabular}




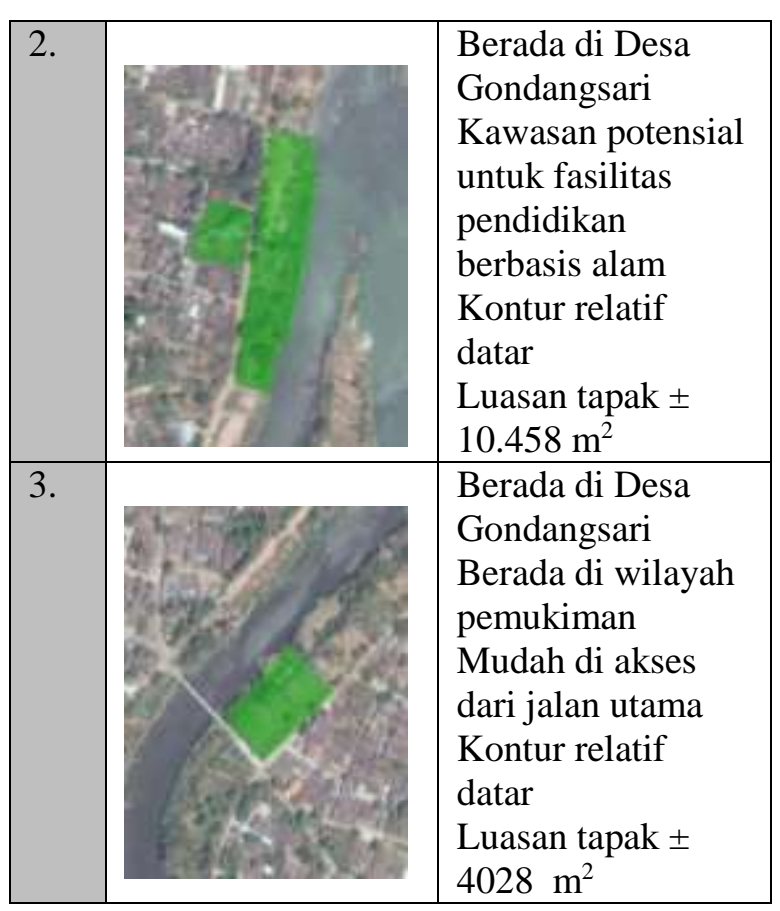

C. Analisis Pencapaian

Pencapaian ke dalam bangunan harus berhubungan langsung dengan jalan yang mudah diakses oleh pelaku kegiatan.

1. Tujuan

Menentukan akses pencapaian yang mudah untuk mencapai lokasi tapak ORB.

2. Dasar Pertimbangan

Akses mudah dikenali pelaku kegiatan, kelancaran arus sirkulasi keluar masuk lokasi tapak, dan kenyamanan sirkulasi.

\section{Proses Analisis}

ME (Main Entrance) ditujukan untuk jalur masuk utama bagi pelaku kegiatan sehingga keamanan lebih terjaga. ME (in, out) berada di bagian utara tapak, karena mudah diakses dari jalan utama yaitu Jalan Raya Cuplik Serenan yang merupakan akses utama menuju tapak kemudian masuk gang dengan lebar 4 meter disebelah selatan jalan utama sampai menuju ke lokasi tapak. SE (in) berada di bagian barat tapak, terdapat sebuah gang dengan lebar 3 meter menuju gang utama yang menjadi main entrance. SE dijadikan tempat pengalihan arus kendaraan jika terjadi kepadatan pada jalur pencapain utama menuju lokasi tapak supaya alur sirkulasi lancar dan efektif (lihat Gambar 2).

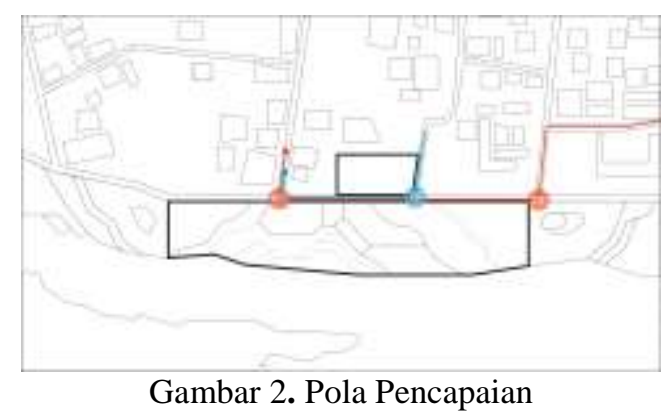

D. Analisis Klimatologi

1. Tujuan

Mendapatkan solusi yang tepat untuk merespon kondisi klimatologi di sekitar tapak.

2. Dasar Pertimbangan
a. Arah pergerakan sinar matahari di sekitar lokasi tapak ORB
b. Intensitas curah hujan di lokasi tapak ORB
c. Arah pergerakan angin di sekitar lokasi tapak ORB

3. Proses Analisis

Kondisi klimatologi pada tapak berupa arah gerak sinar matahari dan pergerakan aliran angina (lihat Gambar 3 dan 4) menjadi pertimbangan dalam perencanaan dan perancangan Sekolah Alam Bengawan Solo di Kabupaten Klaten guna memenuhi kebutuhan ORB akan pencahayaan dan penghawaan alami. Penggunan Ekologi Arsitektur sebagai alat rancang bangun juga mengharuskan perancangan yang mampu meminimalisir energi terutama untuk mengkondisikan pencahayaan dan penghawaan dalam bangunan.

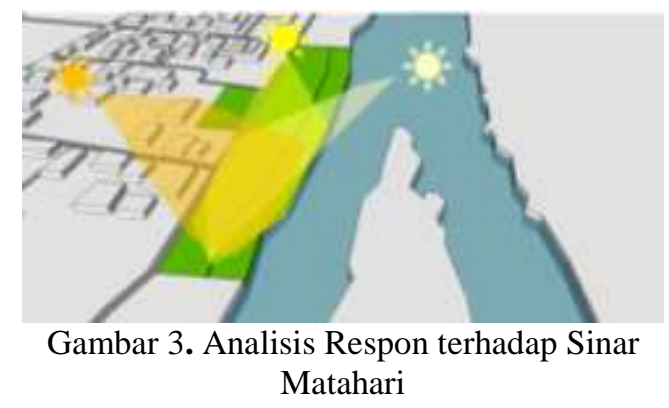




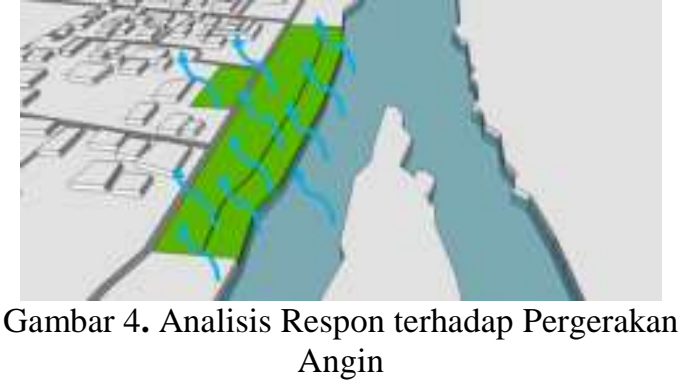

E. Analisis Bentuk dan Gubahan Massa

1. Tujuan

Menentukan hirarki massa yang tersusun dari bentuk dan komposisi massa bangunan Sekolah Alam Bengawan Solo dengan pendekatan Ekologi Arsitektur di Kabupaten Klaten yang direncanakan.

2. Dasar Pertimbangan
a. Bentuk Dasar
b. Jenis Massa
c. Komposisi Massa
d. Gubahan Massa
e. Penampilan Bangunan
f. Sumbu Massa

3. Proses Analisis

Hirarki massa yang dirancang diharapkan mampu mempermudah pelaku kegiatan untuk mengidentifikasi massa bangunan sekolah alam sesuai dengan fungsi massa dan pengelompokkan jenis kegiatan ruang. Hirarki massa tersusun dari beberapa pertimbangan yakni bentuk dasar (lihat Gambar 5), jenis massa, komposisi massa, gubahan massa (lihat Gambar 6), penampilan bangunan, dan sumbu massa.

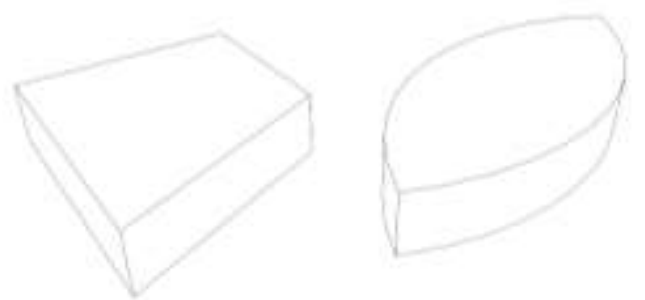

Gambar 5. Bentuk Dasar

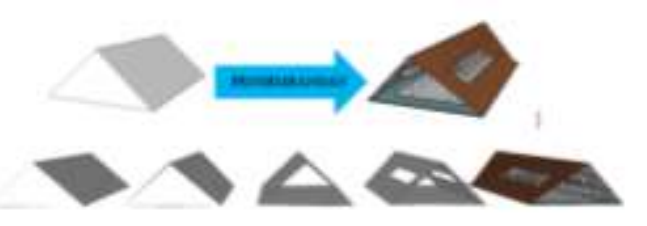

Gambar 6. Proses Gubahan Massa

Komposisi massa yang digunakan pada Sekolah Alam Bengawan Solo adalah komposisi cluster. Karaketer tapak yang membentang dari utara ke selatan menjadikan bentuk tapak memanjang sehingga untuk menyesuaikan karakter tapak tersebut komposisi yang digunakan adalah komposisi linier. Strategi desain untuk memperjelas segmen-segmen yang digunakan pada pola pembelajaran perlu adanyanya pengelompokkan massa bangunan sesuai dengan segmen kegiatannya, maka komposisi yang tepat untuk mengakomodir kebutuh tersebut adalah komposisi cluster (lihat Gambar 7). Kedua komposisi tersebut digunakan dalam perancangan untuk memudahkan siswa dalam mengenali massa bangunan sesuai dengan jenis kegiatannya.

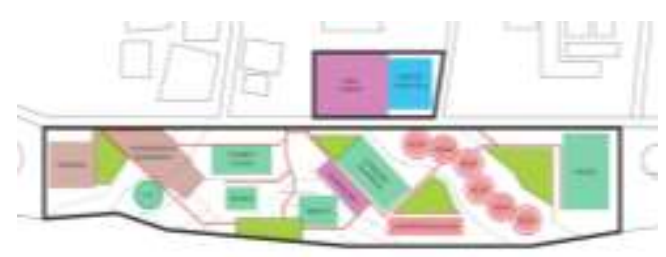

Gambar 7. Komposisi Cluster

F. Analisis Material dan Bahan

1. Tujuan

Untuk memperoleh analisis penggunaan material pada bangunan agar sesuai dengan esensi perancangan Ekologi Arsitektur.

2. Dasar Pertimbangan

Material harus ramah lingkungan mulai dari pengadaan, pengiriman, hingga pengolahannya. Material yang digunakan dalam bangunan ini harus dapat diperbaharui atau dipergunakan kembali sesuai 
dengan esensi perancangan Ekologi Arsitektur.

3. Proses Analisis

Pendekatan Ekologi Arsitektur menjadikan Sekolah Alam Bengawan Solo menggunakan material yang ramah lingkungan sebagai berikut: (lihat Gambar 8)

a. Bambu

Bambu dikenal sebagai bahan bangunan yang sangat mudah diperbaharui karena siklus hidupnya yang sangat cepat yaitu tiga tahun hingga massa panen. Selain itu bambu juga memiliki kekuatan daya rentang yang kuat. Bambu juga merupakan material alami sehingga sisa penggunaanya tidak akan mencemari lingkungan.

b. Kayu

Menggunakan material kayu yang mudah ditemukan di sekitar lokasi tapak. Penggunaan material kayu juga menguatkan suasana sekolah alam sebagai wahana belajar anak.

c. Batu Bata

Kedap air, sehingga jarang terjadi rembesan pada tembok akibat air hujan. Jarang terjadi keretakan pada tembok. Kuat dan tahan lama.

d. Kaca

Untuk keperluan bukaan ruang diperlukan material kaca untuk memasukkan pencahayaan alami kedalam bangunan. Pemanfaatan pencahayaan alami juga merupakan upaya penghematan energi untuk mendukung prinsip Ekologi Arsitektur.
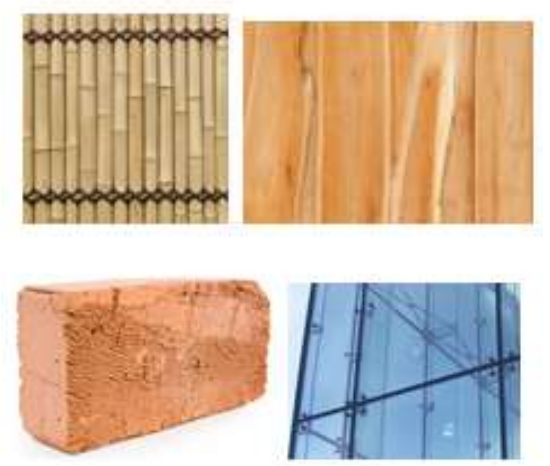

Gambar 8. Material Bambu, Kayu, Batu Bata dan Kaca

(Sumber: rumahidaman87.blogspot.com,2013)

\section{G. Analisis Struktur Bangunan}

1. Tujuan Memperoleh struktur yang tepat pada bangunan Sekolah Alam Bengawan Solo yang direncanakan.

2. Dasar Pertimbangan

a. Kesesuaian jenis struktur dengan karakter dan estetika bangunan yang aman, terbuka, dan akrab.

b. Kesesuaian struktur dengan bentuk dan tampilan bangunan

c. Kondisis tanah pada tapak yang terpilih.

3. Proses Analisis

Bangunan ini akan dominan menggunakan struktur kayu dan bambu. Pemilihan struktur yang digunakan juga mempertimbangkan potensi masyarakat Desa Gondangsari yang terampil dalam mengolah material kayu dan bambu. Struktur juga merespon kondisi tapak yang memiliki kontur tanah yang tidak rata. Kebutuhan ruang dan ketinggian bangunan juga mempengaruhi pemilihan jenis struktur.

\section{a. Sub structure}

Sub structure yang digunakan Sekolah Alam Bengawan Solo yakni pondasi batu kali (lihat Gambar 9) dan pondasi bambu. Hal ini beradasarkan pada 
pertimbangan bahwa dua jenis pondasi tersebut sesuai dengan daya dukung tanahnya. Sesuai untuk beban bangunan yang merupakan bangunan berlantai rendah. Pemilihan sub structure juga mempertimbangkan kontur tanah di daerah aliran Sungai Bengawan Solo yang bergelombang serta aksesbilitas pengangkutan material menuju lokasi obyek rancang bangun.

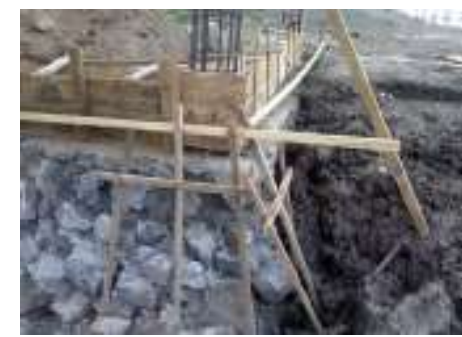

Gambar 9. Pondasi Batu Kali

Sumber : (xdesignmw.files.wordpress.com, 2009)

\section{b. Supper structure}

Supeer Structure yang digunakan Sekolah Alam Bengawan Solo yakni struktur rigid (lihat Gambar 10) dan rangka bambu. Penggunaan supper structure tersebut sesuai dengan tipe bangunan yang semi terbuka. Selain itu, penggunaan rangka bambu juga diharapkan mampu mengoptimalkan potensi kawasan yang terdapat banyak material bambu di sekiar daerah aliran Sungai Bengawan Solo sehingga dirasa lebih efisien. Proses pengerjaan struktur rigid pada desain (lihat Gambar 11) yang mampu dikerjakan oleh warga setempat juga menjadi pertimbangan dalam pemilihan jenis supper structure.

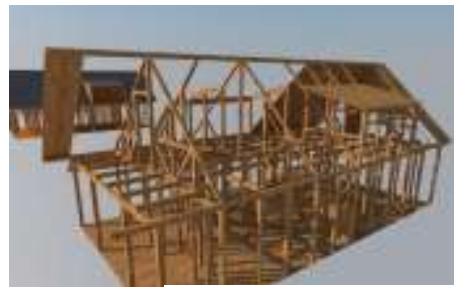

Gambar 10. Sistem Struktur Rigid (sumber: kebun-bambu.blogspot.com, 2013)

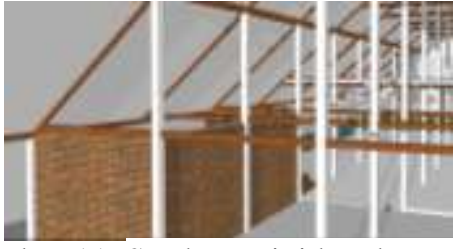

Gambar 11. Struktur Rigid pada Desain

c. Upper structure

Upper Structure yang digunakan

Sekolah Alam Bengawan Solo yakni struktur kayu dan struktur bambu (lihat Gambar 12). Penggunaan kedua jenis struktur tersebut menyesuaikan bentuk sekolah alam yang sederhana dan menggunakan material ramah lingkungan dalam menciptakan bentuk-bentuk atapnya. Struktur atap kayu dan struktur atap bambu juga menyesuaikan dengan jenis sub structure dan supper structure yang menopang di bawahnya. Hal itu dimaksudkan agar tidak memberikan beban yang berlebihan.

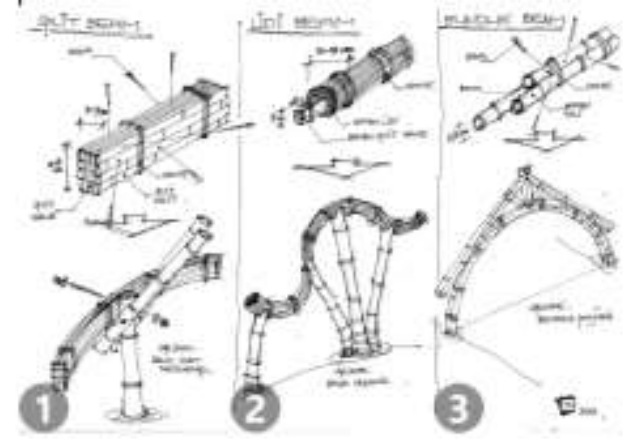

Gambar 12. Sistem Struktur Rangka Atap

Konstruksi Bambu Struktur Organik atau Melengkung

(sumber: Dokumen Adhiwira, 2013)

\section{KESIMPULAN (KONSEP DESAIN)}

Sekolah Alam Bengawan Solo yang dirancang menghadirkan konsep desain untuk menjawab kebutuhan ruang pembelajaran alternatif dan wadah pemberdayaan masyarakat. Konsep desain rancangan mengacu pada pengaplikasian lima esensi Ekologi Arsitektur yang sesuai dengan perancangan obyek rancang bangun, yakni iklim, drainase berkelanjutan, infrastruktur rekayasa, energi, dan pemberdayaan masyarakat (lihat Gambar 13). Konsep desain 
diharapkan mampu menjadi model ruang pembelajaran alternative yang menjawab permasalahan serupa di berbagai daerah. Metode perancangan dan proses analisis yang dilakukan menghasilkan sebuah hasil berupa desain rancangan Sekolah Alam Bengawan Solo dengan pendekatan Ekologi Arsitektur di Kabupaten Klaten sebagai berikut (lihat Gambar 14, 15, dan 16).

$\begin{array}{ll}\text { Nama Bangunan } & : \text { Sekolah Alam Bengawan } \\ & \text { Solo } \\ \text { Lokasi } & : \quad \text { Desa Gondangsari, } \\ & \text { Kecamatan Juwiring, } \\ & \text { Kabupaten Klaten } \\ \text { Luas Lahan } & : 10.458 \\ \text { Luas Bangunan } & : 9.078 \mathrm{~m}^{2} \\ \text { Kegiatan } & : \text { Pendidikan, } \\ & \text { Pemberdayaan, } \\ & \text { Pameran. }\end{array}$

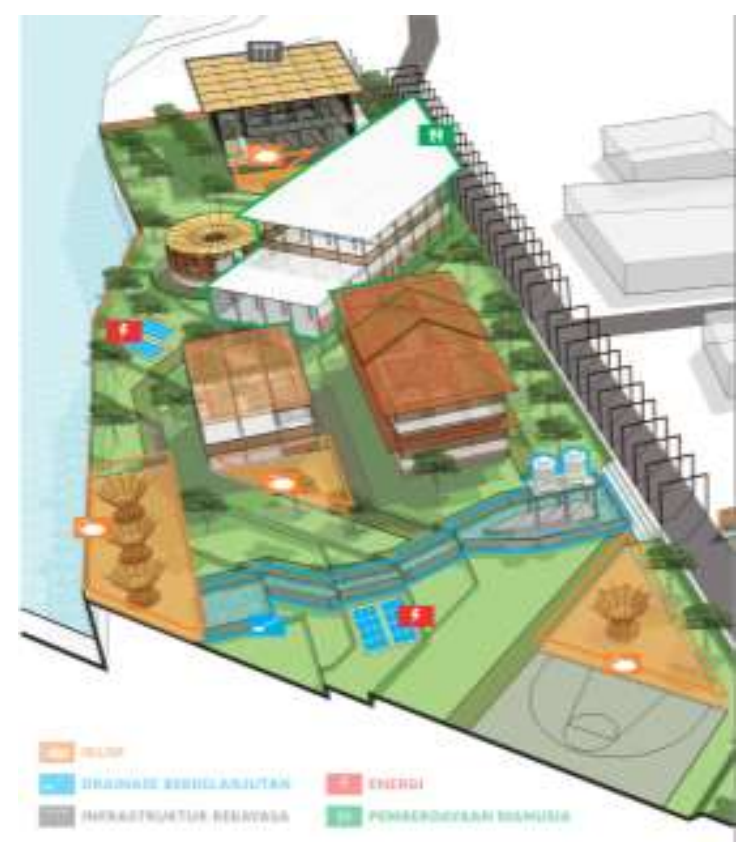

Gambar 13. Aplikasi Ekologi Arsitektur

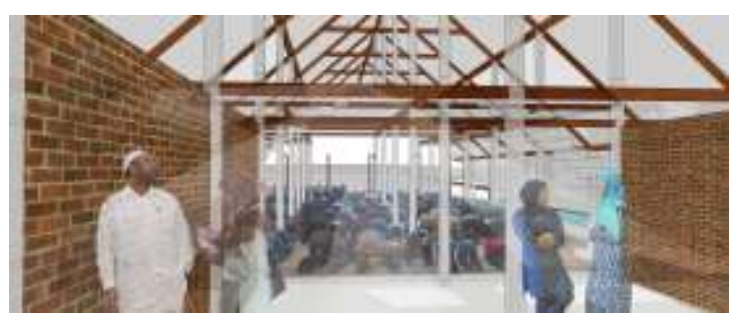

Gambar 14. Perspektif Interior

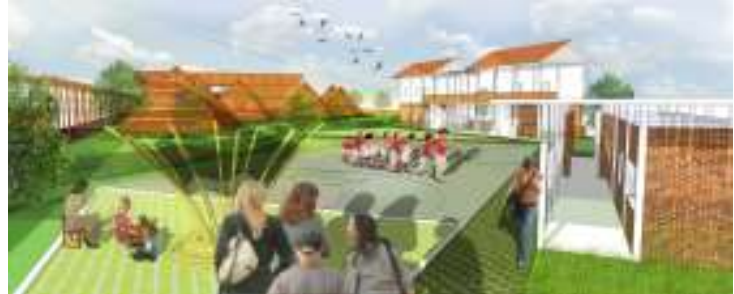

Gambar 15. Perspektif Eksterior

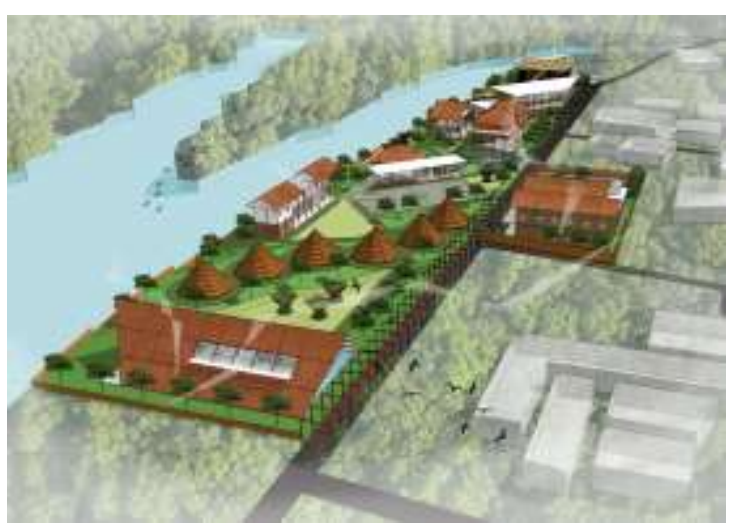

Gambar 16. Perspektif Mata Burung

\section{REFERENSI}

Frick, Heinz. 1998. Dasar-dasar Eko Arsitektur. Yogyakarta : Kanisius. Yuliani, Sri. 2014. Metode Perancangan Arsitektur Ekologi. Solo: UNS Press. kebun-bambu.blogspot.com xdesignmw.files.wordpress.com rumahidaman87.blogspot.com 